Images in...

\title{
A retrosternal retrotracheal multinodular goitre
}

\author{
Dipak Mistry \\ Department of ITU, Homerton University Hospital, London, UK \\ Correspondence to Dipak Mistry, d.a.mistry@btinternet.com
}

\section{DESCRIPTION}

A 58-year-old lady with a history of rheumatoid arthritis on methotrexate therapy was admitted to the intensive care unit for non-invasive ventilation following acute pneumococcal pneumonia. A CT pulmonary angiogram was performed to rule out pulmonary embolus which revealed a retrotracheal mass arising from the thyroid (figure 1). MRI scanning was performed subsequently, and the mass was confirmed to be a retrosternal retrotracheal goitre (figure 2). There was no radiological evidence of collapse of the trachea. The patient was clinically euthyroid with borderline raised free T4 of $23.7 \mathrm{pmol} / \mathrm{l}(9-19)$ and thyroid-stimulating hormone level of $0.1 \mu / 1(0.3-5)$ on acute presentation.
Retrotracheal goitres represent around $4 \%$ of retrosternal goitres - the rest being anterolateral to the trachea. They are thought to arise from the posterior lobes of the thyroid gland and descend through the neck to lie in the posterior mediastinum anterior to the vertebral body. ${ }^{1}$ They can remain silent for many years and are most often incidentally found on radiological imaging or if they grow large enough to cause effects by compression promise due to mild lateral displacement of the trachea which was decompensated by acute infection. Flow volume testing was not performed to delineate this on the intensive care unit.

Management is by surgical excision of the gland. This lady recovered from her pneumococcal pneumonia and is currently being followed up in the ENT clinic with a view to excision in due course.

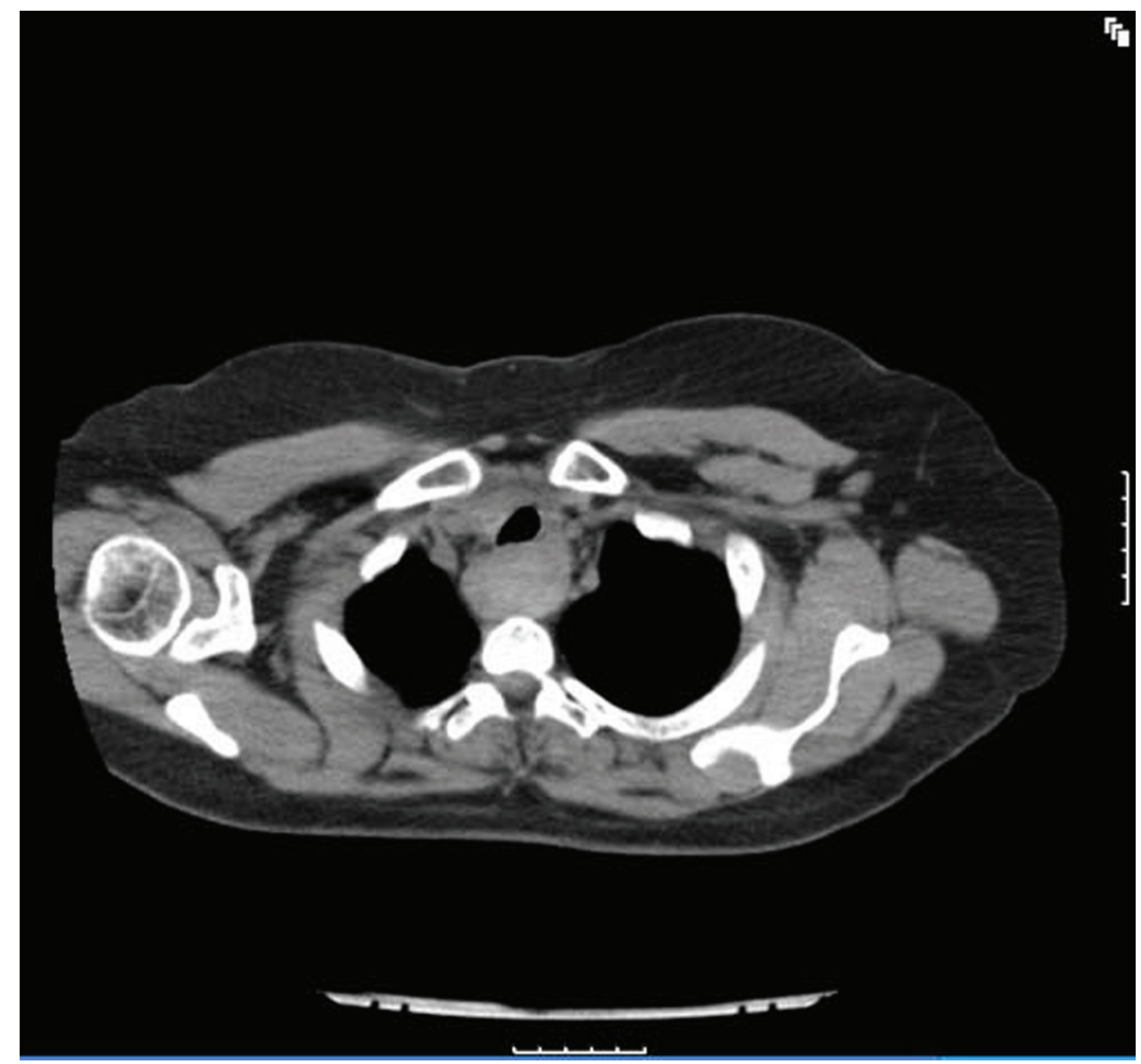

Figure 1 CT chest: a $4.9 \mathrm{~cm}$ retrotracheal mass is demonstrated. 


\section{BMJ Case Reports}

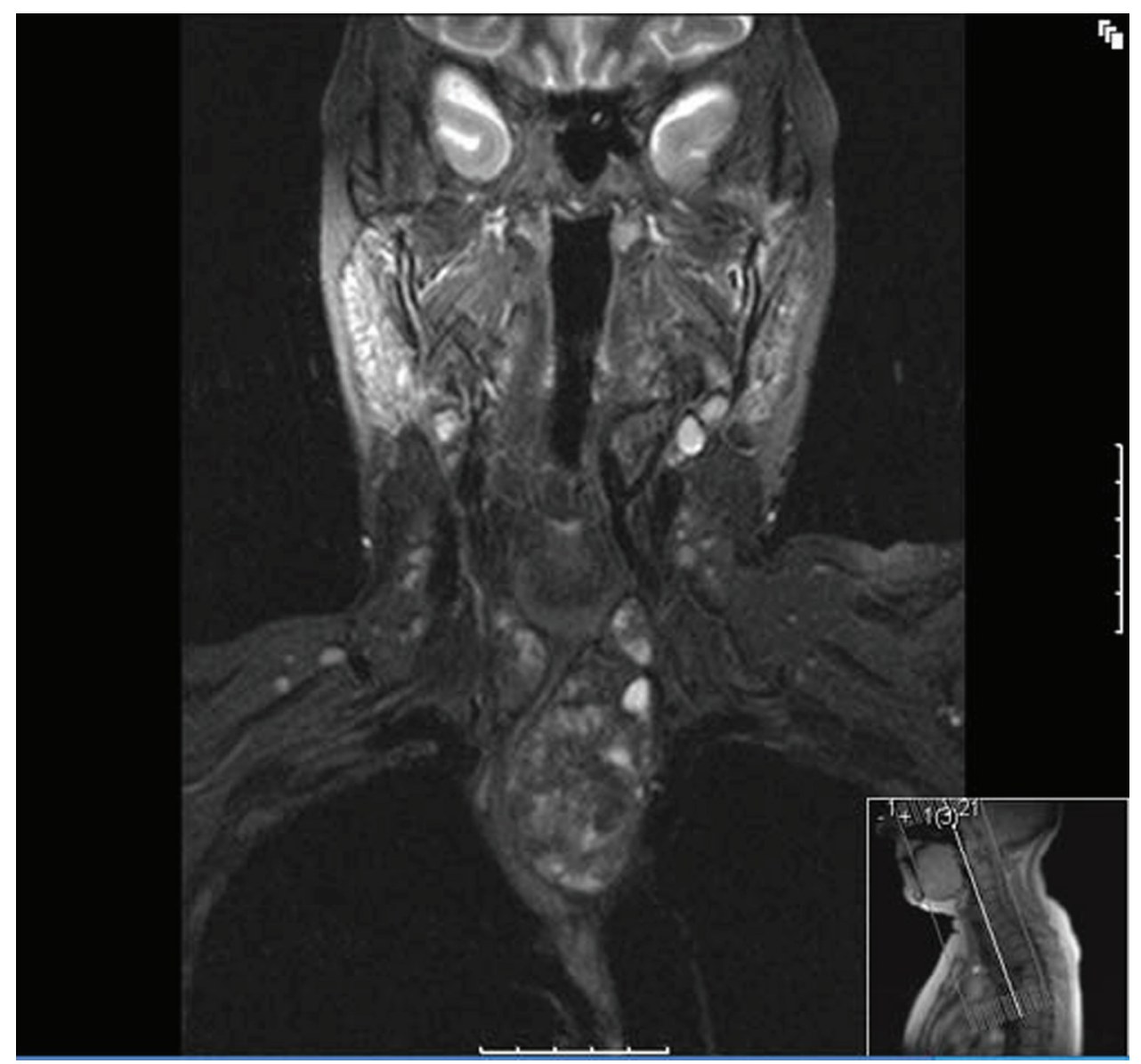

Figure 2 Coronal reformatted T2-weighted MRI neck: the retrosternal retrotracheal goitre is now clearly delineated.

Competing interests None.

\section{REFERENCES}

Patient consent Obtained.

1. De Perrot M, Fadel E, Mercier O, et al. Surgical management of mediastinal goiters: when is sternotomy required? Thorac Cardiovasc Surg 2007;55:39-43.

This pdf has been created automatically from the final edited text and images.

Copyright 2011 BMJ Publishing Group. All rights reserved. For permission to reuse any of this content visit

http://group.bmj.com/group/rights-licensing/permissions.

BMJ Case Report Fellows may re-use this article for personal use and teaching without any further permission.

Please cite this article as follows (you will need to access the article online to obtain the date of publication).

Mistry D. A retrosternal retrotracheal multinodular goitre. BMJ Case Reports 2011;10.1136/bcr.01.2011.3758, date of publication

Become a Fellow of BMJ Case Reports today and you can:

- Submit as many cases as you like

- Enjoy fast sympathetic peer review and rapid publication of accepted articles

- Access all the published articles

- Re-use any of the published material for personal use and teaching without further permission

For information on Institutional Fellowships contact consortiasales@bmjgroup.com

Visit casereports.bmj.com for more articles like this and to become a Fellow 